\title{
ТИПИ ПОРУШЕНЬ ЗАСВОСННЯ ПРОСТОРОВОЇ ЗНАКОВО-СИМВОЛІЧНОЇ СИСТЕМИ ЗНАНЬ У ДІТЕЙ ІЗ ПОМІРНОЮ РОЗУМОВОЮ ВІДСТАЛІСТЮ
}

\author{
Каменщук Т. Д.
}

\section{ВСТУП}

В умовах євроінтеграційних змін, які відбуваються в українській освітній системі, та під впливом нових ціннісних орієнтирів актуальною $є$ проблема пошуку шляхів для підвищення ефективності навчання та виховання в напрямі формування життєвої компетентності дітей із порушеннями розумового розвитку. Пошук оптимальних організаційних форм, змісту та методології педагогічної роботи із цією категорією дітей спрямований здебільшого на їх соціальну адаптацію та зменшення рівня залежності від сторонньої допомоги. Роль посередника на всіх рівнях соціальної взаємодії виконують просторові знаки та символи, за допомогою яких формується цілісність сприймання предметно-просторового оточення та розширення меж взаємоїі з довкіллям. Людина, від народження, опиняється у світі знаків i знакових систем, який створений завдяки як природним умовам, так i соціальному середовищу. Комбінаторна природа побудови знакових систем та їх використання у психічному розвитку людини дуже різноманітні. Теоретичні й експериментальні дослідження переконливо доводять, що за умов широкого застосування знаків став можливим розвиток людської культури загалом і кожної особистості зокрема.

Аналіз стану засвоєння просторової знаково-символічної системи знань у дітей із помірною розумовою відсталістю дозволяє виявити особливості, за характерними ознаками визначено різні рівні та виділено типи порушень їх засвоєння, a саме: гармонійний, дисгармонійний оптичний предметний та дисгармонійний знаковосимвольний просторовий. Тому для підвищення ефективності навчання та виховання дітей із помірною розумовою відсталістю мають бути враховані особливості засвоєння просторової знаково-символічної системи знань з урахуванням структурних типів порушень.

\section{1. Просторова знаково-символічна система знань як феномен психічного розвитку дитини}

Теоретико-методологічну основу для характеристики просторової знаково-символічної системи знань (далі - ПЗССЗ) у нашому дослідженні становлять наукові розвідки про роль знаково-символічних 
структур у розвитку мислення людини (О. Лосєв ${ }^{1}$, Л. Виготський ${ }^{2}$, P. Нємов ${ }^{3}$ ) та гештальтно-фреймовий підхід до організації процесу засвоєння знань (Р. Гуріна ${ }^{4}$ К. Дункер ${ }^{5}$, М. Мінський ${ }^{6}$, В. Тарасун ${ }^{7}$, М. Шехтер $\left.{ }^{8}\right)$.

На підставі аналізу результатів досліджень пізнавальної діяльності у психології, теорії пізнання, нейропсихологіï, нейрофізіології, психолінгвістиці, когнітивній психології (Ф. Блум ${ }^{9}$, Дж. Брунер ${ }^{10}$, Л. Веккер ${ }^{11}$, Л. Виготський ${ }^{12}$, О. Лурія ${ }^{13}$, Н. Максимова, О. Тихомиров ${ }^{14}$, С. Хомська ${ }^{15}$, Л. Цвєткова ${ }^{16}$ й ін.) розглядаємо пізнавальну діяльність щодо засвоєння ПЗССЗ як процесу відображення дійсності, сприймання предметного світу через перцептивний образ до отримання узагальненої картини навколишньої дійсності.

Так, у вивченні комплексу знаків і знакових систем виділяють три основні аспекти: семантичний - відношення знаків до предметів, які ними позначаються; синтаксичний - такий, що пов'язаний співвідношенням знаків одного з одним; прагматичний - такий, що відображає відношення знаків до конкретної діяльності та спілкування.

1 Лосев А. Проблема символа и реалистическое искусство. Москва : Искусство, $1976.367 \mathrm{c}$.

${ }^{2}$ Выготский Л. Психология развития человека. Москва : Смысл ; Эксмо, 2005. $1136 \mathrm{c}$.

${ }^{3}$ Немов Р. Психология. 4-е изд. Москва : Владос, 2003. Кн. 1. 688 с.

4 Гурина Р., Соколова Е. Фреймовое представление знаний : монография. Москва, 2005. 176 с.

5 Дункер К. Структура и динамика процессов решения задач в процессах решения практических проблем. Хрестоматия по общей психологии. Психология мышиления : статьи. Москва, 1981. С. 289-297.

${ }^{6}$ Минский М. Фреймы для представления знаний. Москва, 1979, 123 с.

7 Тарасун В. Превентивне навчання дошкільників 3 порушеннями мовленнєвого розвитку : монографія. Київ, 1998. 255 с.

${ }^{8}$ Шехтер М., Потапова А. О роли и видах образов в познавательных процессах. Психологический журнал. 2001. Т. 22. № 3. С. 57-67.

${ }^{9}$ Блум Ф., Лейзерсон А., Хофстедтер Л. Мозг, разум и поведение. Пер.с англ. Москва : Мир, 1988. 248 с.

${ }^{10}$ Bruner J. The Culture of Education. Cambr., Mass. : Harvard University Press, 2006.

11 Веккер Л. Психика и реальность. Единая теория психических процессов. 1959-1981. Москва : Смысл ; Пет, 2000. 685 с.

12 Выготский Л.С. Психология развития человека. Москва : Смысл ; Эксмо, 2005. 1136 c.

13 Лурия А. Основы нейропсихологии. Москва : Педагогика, 1973. 98 с.

14 Тихомиров О. Психология мышления : учебное пособие для студентов высших учебных заведений. 4-е изд., стер. Москва : Академия, 2008. 288 с.

${ }_{15}^{15}$ Хомская Е. Нейропсихология. 4-е изд. Санкт-Петербург : Питер, 2005. 496 с.

${ }^{16}$ Цветкова Л. Введение в нейропсихологию и восстановительное обучение : учебное пособие. Москва : МПСИ ; Воронеж : НПО «МОДЭК», 2005. 184 с. 
Також Г. Клаусом уведено сигматичний підхід, який презентує «знак як об’єкт». У. Еко, Л. Виготський, О. Веряєв представляють використання знака для комунікативного процесу «людина - людина». У семіотиці термін «знак» розглядається в контексті більш широких понять «знакова система» $\mathrm{i}$ «знакова ситуація». Знакова система трактується як матеріальний посередник у взаємодії інших систем. Проста знакова система $є$ матеріальним посередником, що слугує обміну інформацією між двома системами (Ю. Степанов).

Отже, термін «знак» у науковій літературі вживають різноаспектно, проте завжди знак виступає як заміщувач іншого предмета, явища, властивості. Функції знака полягають у функціональному позначенні, номінативній функції, схематичному позначенні (образ, предмет навколишня дійсність); символічному зображені образів, абстрактних понять; позначенні відношення між об'єктами; виконує функцію автостимуляції, спонукання, організації та регуляції процесів діяльності; формуванні знакових систем і моделі довкілля.

Багатоаспектний аналіз наукових джерел дозволив визначити дефініцію знака як форми, що має матеріальне вираження (образ, схематичне зображення тощо), є засобом репрезентації реальності, несе смислове навантаження, на абстрактному рівні набуває символічного значення.

У науковій літературі поряд із терміном «знак» уживають «символ», що має низку як спільних, так і відмінних істотних характеристик.

Дослідженню особливостей творення та функціонування символів присвячені наукові надбання вчених XX ст. різних галузей, серед них: С. Аверінцев, Ю. Борєв, Ж. Дерріда, І. Ільїн, К. Кереньї, Н. Кулагіна, О. Лосєв, М. Мамардашвілі, А. Нямцу, Є. Панов, Ч. Пірс, М. ПодразаКвятковська, Ф. де Соссюр, В. Толкмачов, М. Шнайдер, Е. Фромм та інші.

Отже, існують різні визначення знака та символу, але більшість науковців стверджують, що знак позначає зміст, а символ його розкриває. Символ - це те, чим зображують знак, він $\epsilon$ засобом, інструментом виявлення змісту знака. Знак - це загальне, символ конкретне. Символ - це конкретне оформлення знака. Символ - умовне позначення якогось предмета, поняття або явища; художній образ, який умовно відбиває яку-небудь думку, ідею, почуття; умовне позначення величини, поняття, запроваджене певною наукою ${ }^{17}$.

Психолого-семіотична класифікація немовних (невербальних) 3С3, що використовуються в навчанні, є більш розгалуженою. Серед них виділяють три такі види: просторові 3С3, за допомогою яких

${ }^{17}$ Выготский Л. Психология развития человека. Москва : Смысл ; Эксмо, 2005. $1136 \mathrm{c}$. 
розкриваються істотні зв'язки, структура явищ у науковому та навчальному пізнанні або відтворюються реальні явища; субстратносубстанційні (сутнісні) 3С3, які використовуються для позначення конкретних властивостей об'єктів або через масштабну деформацію об'єкта відтворюють його фізичні чи функціональні властивості; людські дії, що відтворюють певне реальне явище, подію з вираженням ставлення до неї.

Отже, у навчальній діяльності учнів 3С3 виконують не тільки заміщувальну, але й пізнавальну функцію ${ }^{18}$. Ця функція 3С3 націлена на відображення, відтворення реальності в діяльності учнів, результатом якого є нові знання. За допомогою ЗСЗ відбуваються абстрагування, створюється ідеалізована предметність, забезпечується операційність мислення й інших психічних процесів, цілісність сприйняття й опрацювання змісту. Загалом зазначається, що за допомогою 3С3 утворюється інформаційна основа навчальної діяльності учнів.

У межах дослідницького підходу когнітивної психології (Дж. Брунера ${ }^{19}$ ) навчання ведеться 3 опорою на безпосередній досвід дітей, його розширення у процесі пошукової, дослідницької діяльності, активного освоєння світу. Поняття образу у психології $є$ одним із центральних, оскільки саме образи, відображаючи об'єктивну реальність, становлять зміст психіки об'єкта. Образ - це суб'єктивний феномен, що виникає в результаті предметно-практичної, сенсорноперцептивної, мисленнєвої діяльності, становить цілісне й інтегровані відображення дійсності, у якому одночасно представлені основні перцептивні категорії (простір, рух, колір, форма, фактура тощо), це чуттєва форма психічного явища, що містить в ідеальному плані просторову організацію та часову динаміку, це суб'єктивна картина світу чи його фрагментів, що включає самого суб'єкта, інших людей, просторове оточення й тимчасову послідовність подій.

Психолог С. Рубінштейн ${ }^{20}$ розглядає поняття «образ» як те, що формується під час перетворення інформації, яка поступає із зовнішнього середовища шляхом сприймання та являє собою суб'єктивну форму об'єкта, він є утворенням внутрішнього світу людини. Умовами формування адекватного образу є: активний рух, підтримування окремого мінімуму інформації, що надходить до мозку

18 Дункер К. Структура и динамика процессов решения задач в процессах решения практических проблем. Хрестоматия по общей психологии. Психология мышления : статьи. Москва, 1981. С. 289-297.

${ }^{19}$ Bruner J. The Culture of Education. Cambr., Mass. : Harvard University Press, 2006.

${ }^{20}$ Панок В., Чепелєва Н., Титаренко Т. Основи практичної психології. Київ : Либідь, 2001. 534 с. 
iз зовнішнього та внутрішнього середовища та збереження звичної структурованості інформації. Завдяки зв'язкам, які утворюються між різними аналізаторами, в образі відображаються такі властивості предметів чи явищ, для яких немає спеціальних аналізаторів (величина предмета, вага, форма, регулярність).

Формування образу є складним процесом, що розгортається в часі, упродовж якого відображення все більш відповідає об'єкту, предмету чи події, що відображається. I на кожній його фазі виявляються нові властивості предмета й уточнюються вже виявлені. У процесі відображення відбувається безперервна реконструкція образу в напрямі підвищення рівня його адекватності об'єкту, предмету чи події. Будучи відображенням предметів (і явищ) об'єктивної (що існує поза й незалежно від свідомості людини) дійсності, образ водночас $\epsilon$ суб'єктивним феноменом. Це означає, що він належить його суб'єктові - тілесному індивіду, включеному в багатоаспектний взаємозв'язок явищ матеріального світу, який підпорядковується об'єктивним законам буття. Образ формується на базі досвіду, здобутого людиною. Він тією чи іншою мірою асимілює цей досвід, що особливо виразно спостерігається у випадках, коли йдеться про образи, пов'язані з діяльністю, життєво важливою для людини.

Отже, психічний образ є відображенням об'єктивної реальності і водночас важливою ланкою системи регуляції дій людини; образ $\epsilon$ предметним і суб'єктивним за формою (не може бути відчуженим, відокремленим від суб'єкта); він завжди має прообраз (вихідні дані); його формування - активний процес, під час якого вичерпно використовується інформація з обєктивної реальності, у якій перебуває людина, зміст образу безперервно збагачується, уточнюється та коригується; образ є системним утворенням, яке характеризується багатомірністю й багаторівневістю, основним рівнем образного відображення є сенсорно-перцептивний; образ має цілісний характер, який забезпечує синтез чуттєвого образу і хаотичного набору почуттів; «<..> образ < ..> не становить окремих явищ і предметів, а від початку розвивається й функціонує як єдине ціле»; образ ієрархічний, він розвивається впродовж життя і поступово ускладнюється; образ виконує прогностичну функцію, яка є однією з головних, він $є$ базою для формування системи наших очікувань, прогнозів щодо наслідків наших вчинків тощо; образ має знаково-символічний характер.

Отже, образ - це не копія дійсності, а іiі відображення, продукт розумових процесів і результат взаємодії багатьох внутрішніх функцій, емоцій, почуттів, орієнтацій, поведінки, очікувань тощо.

Як зазначають науковці, наступним етапом еволюції образу у свідомості людини $€$ гештальт. Із проблемою вивчення психіки 3 погляду цілісних структур - гештальтів - працювали німецькі 
психологи М. Вертгеймер, К. Коффка, В. Келеру, які класифікували ідею цілісності образу та незвідність його властивостей до суми властивостей елементів. На їхню думку, предмети нашого оточення сприймаються почуттями не у вигляді окремих об'єктів, а як організовані форми. Сприйняття не зводиться до суми відчуттів, а властивості фігури не описуються через властивості частин.

Гештальт (з нім. Gestalt - «форма», «образ», «структура») просторово-наочна форма сприйнятих предметів, істотні властивості яких не можна зрозуміти шляхом складання їхніх частин. Це функціональна структура, яка впорядковує розмаїття окремих явищ; якість форми, взаємовідношення властивостей.

Формування гештальта відбувається після засвоєння образу. У цьому процесі вагомі цілісність сприймання образів та їх упорядкованість, що досягається завдяки таким принципам: близькість (стимули, розташовані поруч, мають тенденцію сприйматися разом), схожість (стимули, схожі за розміром, контуром, кольором або формою, мають тенденцію сприйматися разом), цілісність (сприйняття має тенденцію до спрощення й цілісності), замкнутість (відображає тенденцію завершувати фігуру так, щоб вона набула повної форми), суміжність (близькість стимулів у часі та просторі), загальна зона (гештальти формують наше повсякденне сприймання нарівні з набутим і минулим досвідом).

Основою гештальта $\epsilon$ контур, що характеризується ступенем різкості і замкнутістю або незамкнутістю обрисів. Сформовані гештальти завжди $є$ цілісною, завершеною структурою, із чітко обмеженими контурами.

Завершальним етапом розвитку образної системи знань, як зауважують науковці (М. Мінський ${ }^{21}$, Ч. Філлмор, 3. Шенк), є фрейм. Фрейм (англ. frame - «рамка», «основа», «скелет») - це мінімальний опис певного явища, факту чи об'єкта, що має властивість, завдяки якій вилучення із цього опису будь-якої складової частини призводить до того, що це явище, факт або об’єкт припиняють правильно класифікувати; рамочна структура ключової ідеї навчального матеріалу, яку можна «накласти» на більшість тем і розділів, виражена у графічній формі. Р. Гуріна 22 вважає, що фрейм - це жорстка конструкція, каркас, який містить як елементи порожні комірки, вікна, рядки, що повинні бути заповнені i можуть багаторазово перезавантажуватись (на відміну від опорних конспектів і структурних схем) новою інформацією.

${ }^{21}$ Минский М. Фреймы для представления знаний. Москва, 1979, 123 с.

22 Гурина Р., Соколова Е. Фреймовое представление знаний : монография. Москва, 2005. 176 с. 
Безперечною перевагою фреймів $\epsilon$ те, що вони мають високу ємність, легко використовуються під час проблемного навчання, передбачають самостійну роботу дітей, що в сучасних умовах розвитку освіти актуально.

Інформація за складання фреймів подається не в «чистому вигляді», a схематично, компактно, згорнуто, у логічній послідовності структуровано в модель. Тому складністю фреймового підходу $\epsilon$ необхідність високого рівня розуміння, узагальнення тексту та вміння передавати його зміст стисло, логічно, інформативно.

Водночас постійне залучення дітей до створення фреймів дає змогу вдосконалити загальнонавчальні вміння учнів, як-от: аналіз, конкретизування, синтез, узагальнення, виділення головного, що забезпечує вдосконалення стратегічної компетенції учня; пояснити сутність ключових понять теми; здійснити компресію вихідного тексту; структурувати, упорядковувати і систематизувати знання, збільшити обсяг пам'яті, швидкість запам'ятовування.

Поняття «фрейм» (frame - «рамка»), уведене М. Мінським ${ }^{23}$ у лінгвістиці, або «сценарій» у програмі штучного інтелекту, грунтується на тому, що розум інтерпретує дані, які були сприйняті в термінах, раніше набутих i перепризначених для опису структур. Фрейми $\epsilon$ способом представлення стереотипної інформації, наприклад: перебування в кімнаті, відвідування магазину, театру тощо. Загалом теорія фреймів, як зазначав М. Мінський, була розроблена для того, щоб пояснити швидкість сприйняття та мислення людини, а також зрозуміти фактичну відсутність ментальних явищ, які б піддавалися спостереженню. Формування системи взаємопов'язаних фреймів використовується як на концептуальному, так i на перцептивному рівнях. Їх формування здійснюється упродовж усього життя та визначається набуттям людиною певного досвіду. Фрейми позначають «набір об'єднаних часовими та причиновими зв'язками понять найнижчого рівня, описують упорядковану послідовність стереотипних подій».

Звернення до фреймів у процесі функціонування концептуальної системи індивіда пов'язане з вирішенням завдань ідентифікації об'єктів і ситуацій, прогнозуванням їхньоъ поведінки та змін, передбаченням розвитку подій, їхнього змісту і внутрішнього зв'язку. Застосування фреймового структурування у процесі навчання значною мірою підвищує рівень комунікативних навичок дітей, дає змогу оптимізувати засвоєння нового матеріалу

Під час навчання функцію таких фреймових структур виконують асоціативні малюнки, символи, схеми, опорні слова та графічні зображення, які сприяють спрощенню, візуалізації тієї інформації, яку

${ }^{23}$ Минский М. Фреймы для представления знаний. Москва, 1979, 123 с. 
необхідно засвоїти. Ураховуючи те, що під час сприйняття й розуміння матеріал потрапляе в пам'ять у згорнутому вигляді, уводити інформацію теж варто структуровано, використовуючи таблиці, схеми, графічні зображення тощо ${ }^{24}$.

Отже, гештальтно-фреймовий підхід $\epsilon$ засобом для виділення у змісті навчання ПЗССЗ системи ключових понять, сформованість яких визначає результативність його засвоєння.

Просторова знаково-символічна система знань - психічна структура внутрішнього відображення дійсності, в основу якої покладені предметно-просторові знаки та символи, які еволюціонують у процесі розвитку людини шляхом формування між ними системних зв'язків ы залежностей, що сприяє засвоєнню суспільного досвіду. Суспільство живе у знаково-символічному просторі, одним з елементів якого є образ. Еволюція кожного образу відбувається у три етапи: на початковому етапі відбувається формування перцептивного образу довкілля (образ об'ємних предметів, площинних практичних зображень, їх упізнавання, розрізнення); на наступному етапі формуються гештальти (площинні контурні символічні зображення); на завершальному - формування фреймів, до яких відносять стереотипні моделі виконання дій, що допомагає забезпечити практичне застосування засвоєних образів та гештальтів.

\section{2. Класифікація структурних типів порушення засвосння} просторової знаково-символічної системи знань у дітей із помірною розумовою відсталістю молодшого шкільного віку

Важкість опанування просторових знаків і символів, які є основою сформованості просторової знаково-символічної системи знань, ускладнює процес навчання, виховання та розвитку дітей із ПРВ.

Відповідно до психофізичних можливостей дітей із ПРВ, ураховуючи їхню слабку пізнавальну активність i незначний обсяг засвоєння інформації, було визначено зміст діагностичних завдань із метою визначення стану засвоєння просторової знаково-символічної системи знань у дітей із помірною розумовою відсталістю. У змісті передбачалося цілісне називання, впізнавання чи розрізнення просторових знаків та символів (далі - ПЗС), пошук їх за аналогією. Загалом завдання для вивчення ПЗССЗ у дітей із ПРВ були ієрархічно вибудовані й об'єднані в чотири блоки. У кожний із них увійшли просторові знаково-символічні засоби, які рекомендовано використовувати у процесі вивчення таких тем: «Світ людей у школі», «Світ речей у школі», «Ознайомлення зі світом природи», «Моє тіло» (програма «Я і Україна», підготовчий клас);

24 Тарасун В. Превентивне навчання дошкільників з порушеннями мовленнєвого розвитку : монографія. Київ, 1998. 255 с. 
підготовчі вправи 3 образотворчого мистецтва (підготовчий клас); «Спеціальна підготовка до письма», «Розвиток слухання - розуміння мовлення вчителя. Розвиток усного мовлення» тощо. До методики увійшли також ПЗС, вагомі для соціалізації дітей із розумовою відсталістю, які в українських програмах ще недостатньо представлені: піктограми, символи та схеми (наприклад: перехід, зупинка громадського транспорту, туалет, хлібний магазин, школа, міліція, пожежна частина, лікарня) $)^{25}$.

Перший блок завдань спрямовувався на дослідження стану розпізнавання та називання оптико-предметних знаків i символів: фотографії людей із найближчого оточення та фотографії предметних зображень, які є в щоденному побуті (кольорові, контурні малюнки та малюнки з опорних крапок). Завдання у другому блоці застосовувалися для дослідження стану розпізнавання та називання предметнопросторових знаків і символів - сюжетних картинок (ілюстрації до казок «Ріпка», «Колобок»). Вони містили два завдання, змістовий матеріал яких передбачений навчальними програмами підготовчого та 2-го класів дисципліни «Українська мова». До третього блоку вміщені завдання, які сприяли вивченню стану впізнавання та називання знаково-просторових знаків і символів, а саме: геометричних фігур (коло, квадрат), цифр $(1,2,3,4,5)$, графічного зображення букв, фраз, словосполучень i речень. Змістовий матеріал завдань підібрано 3 навчальних програмам предметів «Українська мова» $\mathrm{i}$ «Математика» 1-го та 2-го класів. Завдання четвертого блоку були спрямовані на визначення стану знання та називання символьно-просторових знаків $\mathrm{i}$ символів (піктограмних зображень з елементами літер і цифр, символів, схем). Він містив три завдання, змістовий матеріал яких не передбачений навчальними програмами, однак нами були підібрані знаково-символьні засоби, вагомі для соціалізації дітей із ПРВ, що часто трапляються в довкіллі. Загалом до методики ввійшло чотири блоки (сімнадцять завдань), зокрема, кожний блок завдань був спрямований на вивчення ПЗС одного виду.

Аналіз результатів дослідження стану сформованості ПЗССЗ сприяв виявленню їхніх особливостей засвоєння цими дітьми. Під час дослідження було виявлено дітей, які не засвоїли ПЗССЗ. Ці діти переважно не розуміли мовленнєве звернення, не користувалися інструкцією педагога. Також у них спостерігався низький рівень мотивації до спілкування, порушення цілеспрямованих дій із ПСЗ,

25 Каменщук Т. Рівнева шкала оцінювання засвоєння просторовою знаковосимволічною системою знань дітьми 3 помірною та тяжкою розумовою відсталістю молодшого шкільного віку. Освіта осіб з особливими потребами: иляхи розбудови : збірник наукових праць. 2014. Вип. 7. С. 78-83. 
проявлялася загальна байдужість до результату своїх дій або вони виконували неадекватні дії.

Нами також виділені різні структурні типи порушення засвоєння ПЗССЗ. Перший тип - гармонійний, з рівномірним засвоєнням різних видів ПЗССЗ. Другий тип - дисгармонійний оптично-предметний із базовим засвоєнням оптико-предметних i предметно-просторових знаків та символів, за слабкого засвоєння знаково-просторових i символьно-просторових знаків та символів. Третій тип дисгармонійний знаково-символьний просторовий із базовим засвоєнням знаково-просторових і символьно-просторових знаків та символів як основних, 3 незначним засвоєнням або відсутністю засвоєння оптико-предметних i предметно-просторових знаковосимволічних знань ${ }^{26}$.

Аналіз результатів експериментального дослідження показав, що в дітей із ПРВ спостерігався різний рівень засвоєння ПЗССЗ. 3 огляду на це в межах кожної групи були виділені підгрупи.

Зокрема, у групі дітей із гармонійним типом (33\% від загальної кількості обстежених дітей із ПТРВ) виділено дві підгрупи (1А, 1Б) 3 різними рівнями засвоєння усієї ПЗССЗ. Дітей, які були приєднані до другої групи 3 дисгармонійним оптично-предметним типом (46\% від загальної кількості обстежених), за результатами аналізу якісної та кількісної оцінки, виділено у 3 підгрупи (2А, 2Б, 2В). У третій групі (3A) 3 дисгармонійним знаково-символьним просторовим типом підгруп виділено не було, адже їх налічувалося лише 4\% від загальної популяції обстежених. Також у процесі дослідження було виділено дітей, у яких несформовано ПЗССЗ. Усього їх налічувалося $17 \%$ від загальної кількості обстежених.

До підгрупи 1А увійшло $14 \%$ дітей ПРВ. На достатньому рівні засвоїли оптико-предметні та знаково-просторові знаки та символи, на середньому рівні - предметно-просторові та символьно-просторові.

Характеризуючи засвоєння ПЗССЗ у дітей підгрупи $1 \mathrm{~A}$, слід вказати на рівномірний середній рівень їх засвоєння. Вони розуміли зміст інструкції з однієї частини, не могли утримувати в пам'яті вербальну інструкцію із двох частин. Правильно впізнавали та називали різні знаки та символи. Виконували завдання 3 незначною допомогою (вказівний жест педагога), не завжди точно відтворювали спосіб дії, діяли за зразком. Активно долучалися до спільної діяльності 3 педагогом. У них були наявні адекватні маніпуляції 3 оптико-

${ }^{26}$ Каменщук Т. Методика діагностики рівнів засвоєння просторової знаковосимволічної системи знань у дітей з помірною та тяжкою розумовою відсталістю. Актуальні питання корекційної освіти (педагогічні науки): збірник наукових праць. Вип. 8. Кам'янець-Подільський : ПП Медобори-2006, 2016. С. 101-113. 
просторовими знаками та символами. Активне фразове мовлення характеризувалося аграматизмами, у словнику переважали підмети та присудки, використовували речення із 2-3-х слів. Діти проявляли зацікавленість результатами своєї діяльності. Працездатність була достатня.

До підгрупи 1Б увійшли $19 \%$ дітей із дуже низьким рівнем засвоєння ПЗССЗ. Аналіз результатів дослідження свідчив про дуже низький рівень стану засвоєння ПЗССЗ у дітей підгрупи 1Б. Засвоєння оптико-предметних знаків та символів виявилося на дуже низькому рівні, на елементарному рівні - предметно-просторові, знаковопросторові та символьно-просторові знаки та символи.

Характеризуючи засвоєння ПЗССЗ у дітей цієї підгрупи, необхідно вказати на стабільний дуже низький їхній рівень за всіма параметрами. Діти не повністю розуміли зміст завдання, недостатньо орієнтувалися у способах діяльності, використовували зорове орієнтування в їх виконанні. Для них важливіше було те, що поряд були дорослі. Вони впізнавали та показували ПЗС лише за допомогою педагога. Варто зазначити, що до кінця обстеження спостерігалася загальна втомленість дітей цієї підгрупи, вони часто не концентрували увагу на завданнях, швидко губили об'єкт сприймання. Допомогу вони сприймали шляхом зменшення кількості (до двох) запропонованих оптико-просторових знаків і символів. Водночас не утримували в пам'яті вербальну інструкцію, яка містила дві частини. Спостерігалися неадекватні маніпуляції з оптико-просторовими ЗСЗ. Звернене до них мовлення розуміли вибірково, в активному мовленні наявні лише окремі звуки. Ці діти не проявляли зацікавленості до результатів своєї діяльності. Їх цікавили лише яскраві кольорові зображення. Реакція на схвалення їхньої діяльності була адекватна.

Отже, за аналізом результатів дослідження виявлено різні особливості та рівні засвоєння ПЗССЗ дітьми із ПТРВ у межах гармонійного типу.

До дисгармонійного оптико-предметного типу порушення були віднесені діти з різним рівнем засвоєння ПЗССЗ, унаслідок цього розподілені за 3 -ма підгрупами - 2А, 2Б, 2В. Вони становили 46\% від загальної популяції обстежених дітей із ПРВ.

До підгрупи 2А ввійшли $14 \%$ дітей. У результаті підсумкового аналізу виконання всіх запропонованих завдань дітьми із ПТВ підгрупи 2А було визначено низку особливостей. Так, на початку обстеження була помітна цікавість до завдань, але до кінця обстеження простежувалися загальна втомлюваність та зменшення зацікавленості до їх правильного виконання. Діти цієї підгрупи правильно впізнавали та називали знаки та символи, проявляли цікавість до яскравих кольорових зображень ПЗС. У процесі виконання завдань діяли способом зорового співвіднесення, але за великої 
кількості елементів губилися, одразу переходили до хаотичних дій. Під час роботи часто відволікалися від завдань, в активному мовленні вживали речення із 2-3-х слів.

Аналіз результатів дослідження свідчив про середній рівень стану засвоєння ПЗССЗ у дітей підгрупи $2 \mathrm{~A}$. Засвоєння оптико-предметних знаків та символів виявилося на середньому рівні, на цьому ж рівні предметно-просторові, на дуже низькому рівні - знаково-просторові та символьно-просторові.

Характеризуючи особливості засвоєння ПЗССЗ у дітей підгрупи 2A, треба зазначити, що під час виконання завдань першого блоку вони правильно впізнавали та називали оптико-предметні знаки та символи, успішно використовуючи допомогу дорослого у вигляді короткої вербальної інструкції. Водночас діти не утримували в пам'яті вербальну інструкцію 3 кількох частин. За відсутності тривалої зосередженої уваги на конкретному малюнку в них спостерігалась достатня працездатність, але предметні малюнки 3 опорних крапок $\mathrm{i}$ предметні зображення різного розміру не називали, а підбирали аналогічні. У другому блоці завдань відчували складнощі з називанням місця розташування аркуша паперу на столі. Ці діти зуміли лише показати. Впізнавали і називали букви та цифри після допомоги у вигляді короткої інструкції. Найбільш складними для них виявилися завдання із сюжетними малюнками. У них спостерігалися обмеженість сприймання та складнощі через збільшення кількості об'єктів на одній картинці. Виконання завдань четвертого блоку, змістовий матеріал яких передбачав зображення символьно-просторового типу, характеризувалося впізнанням загального в об'єкті. Вихованці цієї групи активно включалися у спільну гру з дорослим. Наявні адекватні маніпуляції з оптико-просторовими ЗСЗ. Вони розуміли мовленнєве звернення, у них наявне активне фразове мовлення з аграматизмами, у словнику переважали підмети та присудки. Проявляли інтерес до результатів своєї діяльності. Працездатність достатня.

Підгрупа 2Б склала 21\% дітей від загальної кількості обстежених. Характеризуючи виконання завдань цієї підгрупи, треба зазначити, що впродовж всього обстеження інтерес до завдання у них був на однаково низькому рівні. Вони впізнавали та називали знаки та символи за користування ними. Також час від часу повторювали назви зображень за дорослим, практично всі завдання виконували 3 допомогою дорослого.

Характеризуючи засвоєння ПЗССЗ у дітей цієї підгрупи, треба зауважити, що вони під час виконання завдань першого блоку правильно впізнавали та називали оптико-предметні знаково-символічні засоби, успішно використовуючи допомогу дорослого у вигляді короткої вербальної інструкції та зосереджуючи свою увагу на конкретному 
малюнку. Водночас у них спостерігалась достатня працездатність. Предметні малюнки 3 опорних крапок та предметні зображення різного розміру - не називали, а підбирали аналогічні. У другому блоці завдань мали найбільше проблем із розташуванням аркуша паперу, який клали на столі лише за зразком дорослого. Геометричні фігури впізнавали та показували за допомогою вербальної інструкції педагога, не впізнавали букви й цифри навіть із допомогою. Складнощі викликали завдання із сюжетними малюнками. У дітей спостерігалися обмеженість сприймання сюжетних малюнків та складність через збільшення кількості об’єктів на одній картинці. Графічне зображення фраз, речень і схем не розуміли. Виконання завдань четвертого блоку, змістовий матеріал яких передбачав символьно-просторові знаково-символічні засоби, характеризувалося впізнанням загального в об'єкті. Активне мовлення перебувало на етапі формування. Працездатність знижена, інтерес до виконання завдань низький.

Аналіз результатів нашого дослідження свідчить, що рівень стану засвоєння ПЗССЗ у дітей із ПРВ підгрупи 2Б був низький. Засвоєння оптико-предметних знаково-символічних систем виявилося на середньому рівні, на дуже низькому рівні - предметно-просторові, на елементарному рівні - знаково-просторові, на дуже низькому рівні символьно-просторові знаки та символи.

До останньої підгрупи (2B) дисгармонійного оптико-предметного типу входило $11 \%$ дітей. Під час виконання завдань діти промовляли полегшені слова та постійно відволікалися (на сторонні звуки (з іншої кімнати), на рухи рук педагога та на іграшки за іншим столом). Увагу зосереджували на короткі проміжки часу та потребували зміни виду діяльності після виконання кожного із завдань. Помилки не оцінювали та жодними способами орієнтування не користувалися.

Характеризуючи засвоєння ПЗСС у дітей підгрупи 2В, треба зазначити, що під час виконання завдань першого блоку вони впізнавали добре знайомі оптико-предметні знаково-символічні засоби (фотографії знайомих дітей, предмети, які $\epsilon$ в найближчому оточенні, та предметні малюнки із зображенням продуктів із щоденного вжитку). Успішно використовували допомогу педагога у вигляді третьої інструкції 3 називанням зображення, зосереджували увагу на конкретному малюнку. У процесі роботи спостерігалась низька працездатність, 3 усіма іншими знаково-символічними засобами діти маніпулювали. Завдання 3 використанням предметно-просторових ЗСЗ викликали в дітей найбільше проблем: аркуш паперу рухали по столу хаотично, не реагуючи на допомогу дорослого. Складнощі викликали завдання із сюжетними малюнками - у дітей спостерігалися обмеженість їх сприймання та складність через збільшення кількості об’єктів на одній картинці. Вони не сприймали сюжету картинки, лише виділяли окремі об'єкти, розглядаючи 
iii, перестрибували 3 одного кінця картини на інший, що свідчило про фрагментарність їхнього сприймання. Діти не зуміли керуватися поставленими завданнями, легко відволікалися від них і губили водночас об’єкт сприймання. Працювати за несприятливих умов не вміли. Кожний додатковий подразник відвертав їхню увагу від об'єкта сприймання. Графічне зображення фраз, речень і схем не розуміли. Виконання завдань четвертого блоку характеризувалося повним нерозумінням інструкцій та самих зображень. Спостерігалося пасивне мовлення, активне мовлення не сформоване. Працездатність знижена, спонтанна активність була мінімальною, інтерес до виконання завдань стабільно низький.

Аналіз результатів дослідження засвідчив дуже низький рівень стану засвоєння оптико-просторових знаково-символічних систем у дітей підгрупи 2В. Засвоєння оптико-предметних знань виявилося на дуже низькому рівні, на елементарному рівні - предметно-просторові. Діти не засвоїли знаково-просторові та символьно-просторові ЗСЗ.

Отже, аналіз результатів дослідження виявив різні особливості та рівні засвоєння за окремими типами ПЗССЗ дітьми із ПТРВ у межах дисгармонійного оптико-предметного типу.

До дисгармонійного знаково-символьного просторового типу ми віднесли дітей із ПРВ, які увійшли в одну групу - 3А, їх налічувалося $4 \%$ від загальної популяції обстежених. Під час обстеження ці діти поводилися агресивно, зминали картинки обома руками, кидали їх у різні боки кімнати. Інтерес до виконання завдань був на однаково низькому рівні, час від часу ехолалічно повторювали назви зображень за дорослим, усі завдання виконували з допомогою дорослого.

Найбільше складнощів у дітей викликали завдання 3 називанням i впізнаванням предметно-просторових 3С3, їх співвіднесенням на тлі кращого рівня впізнавання знаково-просторових та символьнопросторових 3С3. У дітей цієї групи спостерігалися епізодичні спалахи гніву, увага була нестійкою. Вони не здатні були керуватися поставленими завданнями, легко відволікалися від них, втрачали об'єкт сприймання. Спостерігалося пасивне мовлення, активне мовлення виявилося несформованим. Працездатність знижена, спонтанна активність мінімальна, відсутній інтерес до виконання завдань.

Аналіз результатів дослідження засвідчив дуже низький рівень стану засвоєння оптико-просторових знаків і символів у дітей групи 3А. Засвоєння оптико-предметного, предметно-просторового та знаково-просторового типів ЗС3 виявилося на елементарному рівні; водночас символьно-просторові знаки та символи засвоїлися дітьми із ПРВ на дуже низькому рівні.

Отже, за аналізом результатів дослідження виявлено низький рівень засвоєння ПЗССЗ дітьми із ПРВ із дисгармонійним знаковосимвольним просторовим типом. За результатами констатувального 
етапу дослідження було виділено різні особливості засвоєння ПЗССЗ дітьми із ПРВ, підсумковий аналіз яких дозволив виділити три структурні типи порушень засвоєння ПЗССЗ.

Найбільшу групу (46\%) склали діти 3 дисгармонійним оптикопредметним типом порушення ПЗССЗ, у них спостерігався кращий рівень засвоєння оптико-предметних і предметно-просторових ЗСЗ та відносно низький рівень засвоєння знаково-просторових і символьнопросторових. 33\% обстежених становили діти з гармонійним типом, у яких спостерігалося рівномірне засвоєння всіх видів ПЗС. Найменшою була група обстежених дітей (4\%) 3 дисгармонійним просторовим типом порушення. У них помічене краще засвоєння знаковопросторових та символьно-просторових ЗСЗ порівняно 3 оптикопредметними та предметно-просторовими ЗСЗ.

За результатами аналізу виконання завдань методики дітьми 3 порушеннями в розумовому розвитку в межах кожної групи виявлено різні рівні засвоєння ПЗССЗ, що дало можливість виділити їх підгрупи.

Отже, загалом за результатами дослідження, середній рівень засвоєння ПЗССЗ спостерігався в $17 \%$ дітей із гармонійним типом порушення, 3 низьким рівнем виявлено $42 \%$ дітей із дисгармонійним оптико-предметним типом порушення, елементарний рівень спостерігався в дітей усіх 3-х типів порушень (41\% дітей).

У результаті підсумкового аналізу виявлено $14 \%$ дітей із ПРВ, серед загальної кількості досліджуваних нами, із середнім рівнем засвоєння ПЗССЗ, 35\% дітей - із низьким рівнем, 34\% дітей - 3 елементарним рівнем, $17 \%$ дітей не засвоїли ПЗССЗ.

У групі дітей із ПРВ гармонійного типу нами виділено дві підгрупи. До підгрупи 1А віднесено $14 \%$ дітей, у яких спостерігається рівномірний середній рівень засвоєння ПЗССЗ. До підгрупи 1Б включено 19\% дітей із дуже низьким рівнем засвоєння ПЗССЗ. До дисгармонійного оптико-предметного типу включені три підгрупи. До підгрупи 2А включені діти (14\%), які мали низький рівень засвоєння ПЗССЗ. Підгрупа 2Б - діти (21\%), які мали низький рівень засвоєння ПЗССЗ. У підгрупу $2 \mathrm{~B}$ увійшли $11 \%$ дітей, які мають елементарний рівень засвоєння ПЗССЗ. 4\% становили діти дисгармонійного знаковосимвольного просторового типу (група 3А), у яких виявився елементарний рівень засвоєння ПЗССЗ.

Отже, за результатами дослідження було виявлено дітей, які не засвоїли ПЗССЗ, немає дітей із достатнім рівнем їх засвоєння, також установлено, що майже однакову кількість склали діти з низьким (35\%) i елементарним (34\%) рівнями засвоєння ПЗСС3, найменшу групу становили діти 3 розумовою відсталістю (14\%), у яких виявився середній рівень засвоєння ПЗССЗ. 
Нам вдалося охарактеризувати особливості засвоєння ПЗССЗ дітьми iз ПРВ, які мають різні структурні типи порушення, а саме: гармонійний тип із рівномірним засвоєнням різних видів оптикопросторових $3 \mathrm{C} 3$ (33\% дітей серед обстежених), дисгармонійний оптико-предметний тип із ведучим засвоєнням оптико-предметних i предметно-просторових знаково-символічних засобів, за слабкого засвоєння знаково-просторових і символьно-просторових ЗСЗ (46\% дітей), дисгармонійний знаково-символьний просторовий тип is ведучим засвоєнням знаково-просторових і символьно-просторових ЗС3, за незначного засвоєння або відсутності засвоєння оптикопредметних і предметно-просторових 3С3 (4\% дітей).

Отже, у розробленій методиці вперше репрезентовано показники стану засвоєння ПЗССЗ дітьми із ПРВ, також визначено, що діти із ПРВ становлять складну та неоднозначну групу приблизно однакового віку, мають, як показали результати дослідження, різні потенційні можливості засвоєння ПЗССЗ.

На основі отриманих результатів вивчення специфіки опанування ПЗССЗ дітьми із ПРВ за оптико-предметними, предметнопросторовими, знаково-просторовими та символьно-просторовими видами знаків і символів можна спланувати корекцію загальних психічних процесів та підвищити результативність роботи із просторовими знаками та символами, яка повинна будуватися з урахуванням виявлених характерних особливостей i складнощів у розвитку ПЗССЗ та їхніх психологічних механізмів.

\section{ВИСНОВКИ}

У процесі дослідження було виділено чотири групи ПЗССЗ, а саме оптико-предметні (фотографії людей із найближчого оточення та предметних зображень, які є в щоденному побуті (кольорові, контурні малюнки та малюнки 3 опорних крапок); предметно-просторові (сюжетні картинки), знаково-просторові (геометричні фігури (коло, квадрат), цифри (1, 2, 3, 4, 5), графічне зображення букв, фраз, словосполучень і речень); символьно-просторові (піктограмні зображення $з$ елементами букв і цифр, символами, схемами). Також розроблено діагностичні завдання та систему оцінювання якості їх виконання, у якій враховано розуміння дітьми із ПРВ змісту інструкції, впізнавання, співвіднесення або знаходження за аналогією оптикопросторового зображення, стан сформованості мовлення. Це дало змогу визначити якісні особливості та рівень засвоєння ПЗССЗ дітьми цієї категорії.

Методика дослідження дала змогу визначити своєрідність засвоєння ПЗССЗ. Особливості засвоєння ПЗССЗ дітьми із ПРВ виявилися різними. Зокрема, виявлено $17 \%$ дітей, які не засвоїли ПЗССЗ, у 33\% 
обстежених дітей визначено гармонійний тип, спостерігалося рівномірне засвоєння всіх видів ПЗСС 3 , у $46 \%$ дітей виділено дисгармонійний оптичний предметний тип порушення засвоєння ПЗССЗ, у них спостерігалося переважно краще засвоєння оптикопредметних і предметно-просторових знаків та символів, відносно низьке засвоєння знаково-просторових і символьно-просторових $3 \mathrm{C} 3$, у $4 \%$ дітей виявлено дисгармонійний знаково-просторовий тип порушення ПЗССЗ, який характеризувався кращим засвоєнням знаково-просторових і символьно-просторових ЗСЗ. Також виявлено різні рівні засвоєння ПЗССЗ і встановлено, що в найбільшої кількості дітей (30\%) наявний низький рівень засвоєння ПЗССЗ, у частини дітей із ПРВ виявлено середній (26\%) та нижче середнього (27\%) рівні засвоєння ПЗССЗ. Із достатнім рівнем засвоєння ПЗССЗ дітей не виявлено.

Отже, для підвищення ефективності навчання та виховання дітей із помірною розумовою відсталістю мають бути враховані вищезазначені особливості засвоєння просторової знаково-символічної системи знань 3 урахуванням наведених структурних типів порушень.

\section{АНОТАЦІЯ}

У статті звернено увагу на проблеми пошуку шляхів підвищення ефективності навчання та виховання в напрямі формування життєвої компетентності дітей із порушеннями розумового розвитку 3 урахуванням стану сформованості просторової знаково-символічної системи знань у дітей молодшого шкільного віку 3 помірною розумовою відсталістю.

У матеріалах представлено теоретико-методологічний аналіз дефініції «просторова знаково-символічна система знань». Просторові знаки та символи використовують як опору для полегшення засвоєння будь-якого роду навчальної інформації під час навчання дітей, а для дітей із помірною розумовою відсталістю вони виступають одним 3 основних засобів не лише навчання, але й соціалізації. Визначено, що дітьми зі значними порушеннями розумової діяльності просторові знаки та символи засвоюються краще, порівнюючи 3 іншого роду інформацією, зокрема вербальною, водночас спостерігаються уповільнений темп та специфіка їх засвоєння.

Подано класифікацію структурних типів порушення засвоєння просторової знаково-символічної системи знань у дітей із помірною розумовою відсталістю молодшого шкільного віку. За результатами аналізу стану засвоєння просторової знаково-символічної системи знань у дітей із помірною розумовою відсталістю визначено особливості, за характерними ознаками яких представлено різні рівні, виділено типи порушень їх засвоєння, а саме: гармонійний, 
дисгармонійний оптичний предметний та дисгармонійний знаковосимвольний просторовий.

\section{ЛІТЕРАТУРА}

1. Блум Ф., Лейзерсон А., Хофстедтер Л. Мозг, разум и поведение. Пер. с англ. Москва : Мир, 1988. 248 с.

2. Веккер Л. Психика и реальность. Единая теория психических процессов. 1959-1981. Москва : Смысл ; Пет, 2000. 685 с.

3. Винарская Е. Раннее речевое развитие ребенка и проблемы дефектологи: Периодика раннего развития. Москва : Просвещение, 1987. $134 \mathrm{c}$.

4. Выготский Л. Психология развития человека. Москва : Смысл ; Эксмо, 2005. $1136 \mathrm{c.}$

5. Гурина Р., Соколова Е. Фреймовое представление знаний : монография. Москва, 2005. $176 \mathrm{c.}$

6. Дункер К. Структура и динамика процессов решения задач в процессах решения практических проблем. Хрестоматия по общей психологии. Психология мылиления : статьи. Москва, 1981. С. 289-297.

7. Запорожец А. Избранные психологические труды. Москва : Директ-Медиа, 2008. 1287 с.

8. Каменщук Т. Рівнева шкала оцінювання засвоєння просторовою знаково-символічною системою знань дітьми 3 помірною та тяжкою розумовою відсталістю молодшого шкільного віку. Освіта осіб 3 особливими потребами: шляхи розбудови : збірник наукових праць. 2014. Вип. 7. С. 78-83.

9. Каменщук T. Методика діагностики рівнів засвоєння просторової знаково-символічної системи знань у дітей з помірною та тяжкою розумовою відсталістю. Актуальні питання корекиійної освіти (педагогічні науки) : збірник наукових праць. Вип. 8. Кам'янецьПодільський : ПП Медобори-2006, 2016. С. 101-113.

10. Лурия А. Основы нейропсихологии. Москва : Педагогика, 1973. $98 \mathrm{c.}$

11. Лосев А. Проблема символа и реалистическое искусство. Москва : Искусство, 1976. 367 с.

12. Немов Р. Психология. 4-е изд. Москва : Владос, 2003. Кн. 1. $688 \mathrm{c}$.

13. Минский М. Фреймы для представления знаний. Москва, 1979, $123 \mathrm{c}$.

14. Панок В., Чепелєва Н., Титаренко Т. Основи практичної психології. Київ : Либідь, 2001. 534 с.

15. Тарасун В. Превентивне навчання дошкільників 3 порушеннями мовленнєвого розвитку : монографія. Київ, 1998. 255 с. 
16. Тихомиров О. Психология мышления : учебное пособие для студентов высших учебных заведений. 4-е изд., стер. Москва : Академия, 2008. 288 с.

17. Хомская Е. Нейропсихология. 4-е изд. Санкт-Петербург : Питер, 2005. $496 \mathrm{c}$.

18. Цветкова Л. Введение в нейропсихологию и восстановительное обучение : учебное пособие. Москва : МПСИ ; Воронеж : НПО «МОДЭК», 2005. $184 \mathrm{c}$.

19. Шехтер М., Потапова А. О роли и видах образов в познавательных процессах. Психологический журнал. 2001. Т. 22. № 3. C. 57-67.

20. Bruner J. The Culture of Education. Cambr., Mass. : Harvard University Press, 2006.

\section{Information about the author:}

Kamenshchuk T. D.,

Candidate of Pedagogical Sciences, Ukrainian Scientific and Methodical Center for Practical Psychology and Social Work,

Director of the Educational and Methodological Center of the Psychological

Service of the Education System of Vinnytsia Region 98, Chapayev Highway str., Kyiv, 02000, Ukraine 